\title{
Factors Affecting The Decision Of Home Buying Of Millenial During The Covid-19 Pandemic
}

\author{
Pantri Heriyati $^{\mathrm{a} *}$, Dewi Tamara ${ }^{\mathrm{b}} *$, Natasya Ilkovicha Saimanc*, Retno Kusuma Ningrum ${ }^{\mathrm{d} *}$, Robi \\ Sugihartono Suriae ${ }^{\mathrm{e} *}$ \\ a,b,c,d,e $*$ Management Department, Binus Business School, Bina Nusantara University, Jakarta, Indonesia, \\ Email : dtamara@binus.edu
}

Article History: Received: 10 November 2020; Revised 12 January 2021 Accepted: 27 January 2021; Published online: 5 April 2021

\begin{abstract}
The purchase decision of buying a house or property is still considered important for young people. This paper aims to examine the factors related to purchase decision in buying a house during the pandemic Covid-19 that now has been lasted for almost one year. We considered feng shui factors as one of the important reasoning because the Chinese belief for the position and direction of the house will impact the occupants. Another variable are brand reputation and financial aspects. We run the data with regression to identify the relation and magnitude of independent to dependent which is property purchase decision. We focus on millennials cohort because they are the driver in the workforce and hit by the pandemic condition. Our sample consists of 112 of millennials that lived in Jakarta greater area.
\end{abstract}

Keywords:

\section{Introduction}

In early 2020, the Covid - 19 epidemic occurred, which according to the World Health Organization (WHO), Covid - 19 was an infectious disease caused by the corona virus which was recently discovered and began to plague in Wuhan, China in December 2019. And now Covid - 19 has caused a pandemic that has hit many countries around the world (who.int/indonesia, 2020). Indonesia is no exception; it has also experienced the Covid-19 pandemic where this pandemic has created a domino effect into a social and economic problem that has hit all levels of society. This is evident from Indonesia's economic growth in the first quarter of 2020 minus 5.32 percent (idxchannel.com, 2020). According to the Ministry of Industry, around $60 \%$ of industries were affected due to the Covid-19 pandemic. Various strategies were prepared in various ways to restore industries affected by the pandemic (cnbcindonesia.com, 2020). However, in 2020 the Indonesian property market is expected to be vibrant. Property means real estate, house, land, shop, building or warehouse (propertyindonesia.co.id, 2020). In order to survive during a pandemic, many property market players have reduced property prices in order to attract consumers. Based on data from Rumah.com (2020) that in the second quarter of 2020 there was a correction in property prices, with a downward trend in prices since April 2020.

Then in the third quarter of 2020, the national property market is expected to improve, where the property market has adjusted to the new normal situation (business.tempo.co, 2020). This is the right opportunity for people from the baby boomer's generation to the millennial generation who want to buy property, either to live in or use themselves or as a means of investment. According to the definition of the Big Indonesian Dictionary, the millennial generation is the generation born in the 1980s and 1990s (kbbi.kemdikbud.go.id, 2020). The number of millennial generation in 2019 reached 24 percent or 64.3 million of the population in the productive age category (14 - 64 years), which amounted to 179.1 million (67.6 percent of Indonesia's population) (IDN Research Institute, 2019)). This significant number of millennial generations can become a very large potential segment that is worked on by property developers (Ekonomi Bisnis.com, 2020). During the current pandemic, it is actually the right moment for millennial generation to invest in property, because the selling price can generally reach its current lowest position. Even after the pandemic ends, property prices can be corrected by up to $10 \%$ (Properti.kompas.com, 2020). However, it is necessary to know and understand how the millennial generation determines the occupancy criteria they will choose, especially during the current Covid-19 pandemic, so that the right property marketing strategy will be obtained for the millennial generation market.

According to Mulyano et al., (2020), for the millennial generation in deciding to buy a residence there are factors which are the main considerations, namely the factors of location, ease of access, price, design and aesthetic aspects, developer brand, land ownership, facilities. and physical attributes. Whereas in Redjo's research, Wijayaningtyas, Iskandar (2019) stated that the factors that influence home purchase decisions by the millennial 
generation are perceptions of behavioral control with indicators including perceptions of: the house building process, the cost of maintaining the house, the house looks comfortable, the house price, and home installment prices. In the author's previous research, it was found that feng shui beliefs and superstitious beliefs also influenced home purchase decisions by both ethnic Chinese and non-Chinese descendants (Heriyati, Saiman, Kusumaningrum, Suria, 2020). According to Chang \& Lin (2015), for people in Asia, in determining home purchase decisions, it is strongly influenced by feng shui beliefs. This was reaffirmed by Sia \& Lu (2006) who stated that in the ethnic Chinese community, belief in feng shui can guide humans to live in harmony with the world and others, and improve aspects of life including luck. In addition, research conducted by Handayani (2009) found that feng shui beliefs were one of the factors that influence home purchase decisions. The millennial generation also considers location, ease of access, price, design and aesthetic aspects, developer reputation, land ownership and facilities, physical attributes in making house purchase decisions (Mulyano et al., 2020). The large number of Indonesian millennial generations and the pandemic phenomenon that has a significant impact on life aspect, encourages the study to examine the extent to which factors such as financial aspects, brand developers, access, and feng shui beliefs influence the decision to buy a house by the millennial generation.

\section{Research Problem}

The research that has been done before is a lot about things that influence home buying decisions by consumers with various demographic criteria, including factors that influence home buying decisions by the millennial generation. However, there is still very limited research on the factors that influence the decision to buy houses by millennial generation in the current Covid-19 pandemic situation (Mulyano et al., 2020; Redjo, Wijayaningtyas, Iskandar, 2019; Sulistyawati \& Santosa, 2019; Kurniawan et al. ., 2020). This research will focus on the millennial generation in the Jabodetabek area during the pandemic era with a conceptual framework built on the factors that influence home purchase decisions in previous studies including financial aspects, brand developer, access and feng shui trust.

Property buying behavior is part of the development of consumer financial behavior. So that the financial aspect factors have a significant influence in purchasing decisions (Anastasia, 2015). The financial aspect is considered an important factor in influencing the decision to buy a house by the millennial generation. Previous research has also shown that affordability and inadequate income can be classified as important barriers to owning a house (Abidoye, Puspitasari, Sunindijo, 2020). Purchasing property from a reputable developer will give consumers a feeling of security in investing or buying property for their own use so that brand developers play an important role in encouraging consumers to decide to buy property (Rahadi, Wiryono, Koesrindartoto, 2014). In the residential market, a residence is said to be attractive, by providing easy access to important public facilities (Kauko, 2006). In addition to financial aspects, brand developer and access factors, feng shui trust factors are known to have an influence on home purchase decisions (Heriyati, Saiman, Kusumaningrum, Suria, 2020).

WHO (World Health Organization) stated that the Covid-19 pandemic is expected not to last soon and therefore the world must prepare for the next pandemic after the pandemic due to the Covid-19 virus (Harianhalmahera.com, 2020). The pandemic that has occurred has affected aspects of people's lives and caused changes in the way of doing business and consumer behavior (Donthu \& Gustafsson, 2020) including consumers from the property business, which is one of the businesses that is severely affected by Covid-19 (McKinsey.com, 2020). Therefore, knowledge of the factors that influence home purchase decisions by millennial generations in the pandemic era is important to fill the gaps in previous research and as a basis for dealing with this pandemic.

\section{Literature Review}

Milenial Generation

The IDN Research Institute classifies the millennial generation into 2 (two) large groups, namely millennial juniors where those born between 1991 - 1998, while millennial seniors are millennial groups born between 1983 - 1990. Then it was also found that the millennial generation population was in the range 20 - 35 years old reaches 24 percent, namely 63.4 million people from the productive age category (14 - 64 years), which amounts to 179.1 million people (67.6 percent) of the total population of Indonesia, which number is which is very significant (IDN Research Institute, 2019).

Millennials tend to adapt more quickly to change, tend to want to get fast and up-to-date results, in the sense that more real-time is preferred. Ease of access, speed, convenience, and exploration of experiences are also the tendencies of the millennial generation (Gatra, 31 January 2018). Ali \& Purwandi (2017) convey that one of the characteristics of the millennial generation is being connected through the role of the internet and social media. The life of the millennial generation, which is inseparable from technological advances, has formed the millennial generation into a generation with the characteristics of open, creative, informative and productive communication. In addition, the economic, political and social dynamics faced in the process of growth and development of the millennial generation allow each individual to have a character that upholds freedom, is critical, courageous and open minded (kemenpppa.go.id, 2018). 
In a business context, it is very important to understand the characteristics of the millennial generation so that it can be used to determine marketing strategies targeting the millennial segment. Research on the millennial generation is something that needs to be done considering its large population and unique forms of consumption, so a strategy is needed to offer products and services that can influence the intention to buy which can continue with the positive experience that lead to the purchase and using of products and services (Küster et al., 2016 as quoted by Moreno et al. 2017).

\subsection{Property Purchase Decision}

Previous research to understand consumer behavior in purchasing decision making has been carried out. According to Stankevich (2017), consumer purchasing behavior is a series of processes in which individuals seek, then choose, decide to buy, and use them, and or choose to no longer use these goods or services according to the satisfaction they want or need and other influencing factors. Purchasing decision making by consumers has a correlation with consumer behavior towards product offerings, so a better and deeper understanding of consumer behavior and purchasing strategies can provide greater opportunities to strengthen marketing campaigns and increase success in competitive markets. Ramya \& Ali (2016) stated that by identifying and understanding the factors that influence consumers in making purchasing decisions, products can develop strategies, unique product offerings, advertising campaigns that are more efficient and in accordance with the needs and ways of thinking of targeted consumers.

Mariadas et al., (2019) said buyers will consider the factors that are most important to them, before making a property purchase. Mulyano et al., (2020) found that the preference for home purchases by millennial generation can be divided into several indicators, namely location, accessibility, price, physical attributes, facilities, design and aesthetic aspects, developer reputation and land ownership. These indicators are taken into consideration in making home purchase decisions by millennial generation.

\subsection{Financial Aspect}

Property buying behavior is part of the development of consumer financial behavior and financial aspects have a significant influence on decisions. According to Agarwal et al., (2014) there are various decisions that consumers need to make to buy and own a house, namely the price of a house or how much it costs to buy a house; mortgage requirements when funding home purchases on a mortgage basis; refinancing during the mortgage cycle; possibility of default during the mortgage period.

Previous research to determine the effect of financial aspects on home purchase decisions has been carried out. When property prices decrease, investment in property increases. Eze \& Lim (2013) state that financial factors that can influence property purchase decisions are protection from inflation, low prices, low investment, the amount of income and high interest rates. Property prices have a big impact on investment because investors will consider their ability to make purchases. Access to a mortgage loan will also provide financial support and have a positive influence on purchasing decisions. Research by Kurniawan et.al (2020) found that millennial home purchase decisions are influenced by structural, location, and financial attribute factors. In line with the research above, the financial aspect, namely price, turns out to be the main determining factor for buyers in deciding to choose a property, followed by products (Maoludyo \& Aprianingsih, 2015).

\subsection{Brand Reputation}

The definition of brand developer according to Fah and Cheok (2008) quoted from Viitanen (2004) is formed from the image generated by real estate development, the concept offered, its physical and operational functions, the performance provided and the service difference with other competitors. The success of a brand developer is resulted from the good reputation of the developer itself. So that brand developers have an important role in being one of the considerations for consumers to make property purchase decisions. In Rahadi's (2013), it is found that it is normal for housing developers in Indonesia to mention their brand / brand in property advertisements to increase housing sales. Real estate developers will have a better reputation and brand if they successfully interpret what consumers need, take action in a professional manner, provide products on time according to agreements, maintain product quality, and support consumers with good after-sales service, all of which will make real estate developers have a better reputation and brand. Real estate developers with good brands will be in a better position to bid on prices, compared to real estate developers who are just starting up and launching their initial product (Rahadi et al., 2013).

According to the a study by Jung et al. (2018) that the millennial generation has a tendency for high mobility and in terms of housing prefers a place to live in urban areas due to easy access to facilities that support their daily activities. Accessibility of a location is the ease of entering and exiting using a transportation system and land use patterns are indicated as important aspects of residential locations (Mulyano et al., 2020). Ease of access includes: 
1) Close to stations or modern public transportation, such as MRT, LRT, Busway, KRL.

2) Easy direct access to and from main roads and toll roads.

3) Close to regional facilities (schools, hospitals, markets, etc.)

This criterion arises because the needs of today's millennials are more specific. The distance to the work place is getting farther, and traffic jams are the main considerations where the house must be close to modern public transportation. Regular public transportation such as minibus, bus is felt to be ineffective due to higher levels of congestion. Based on information from Hei \& Dastane (2017) which explains that there is a positive and significant influence between the purchase of a dream home with location factors, environmental completeness factors, financial factors, environmental management factors, and demographic factors. The location factor explains that the distance factor makes it easier for access to public transportation, hospitals / schools, workplaces, relatives, and shopping centers.

\subsection{Feng Shui Belief}

In the Chinese community, belief in feng shui can guide people to live in harmony with the world and everyone, and improve every aspect of life, including luck (Sia \& Lu, 2006). According to Chang \& Lin (2015), in Asia, feng shui belief has become a significant factor in purchasing a home. Feng shui beliefs refer to the direction towards the house; ground level; big tree in the front yard; located at a T-shaped junction; earth-pocket form; fanground form; the main front door parallel to the rear door; the position of the kitchen right next to the bedroom; the total number of stairs. Chang and Lien (2015) found feng shui affects home prices and home buyers.

Likewise, according to Handayani (2009) found that feng shui beliefs are one of the factors that influence home purchase decisions. In the previous author's research, feng shui beliefs and superstitious beliefs influence home purchase decisions for both ethnic Chinese and non-Chinese descendants in the Jabodetabek area (Heriyati, Saiman, Kusumaningrum, Suria, 2020). Based on literature and research background, we build a conceptual model as follows :

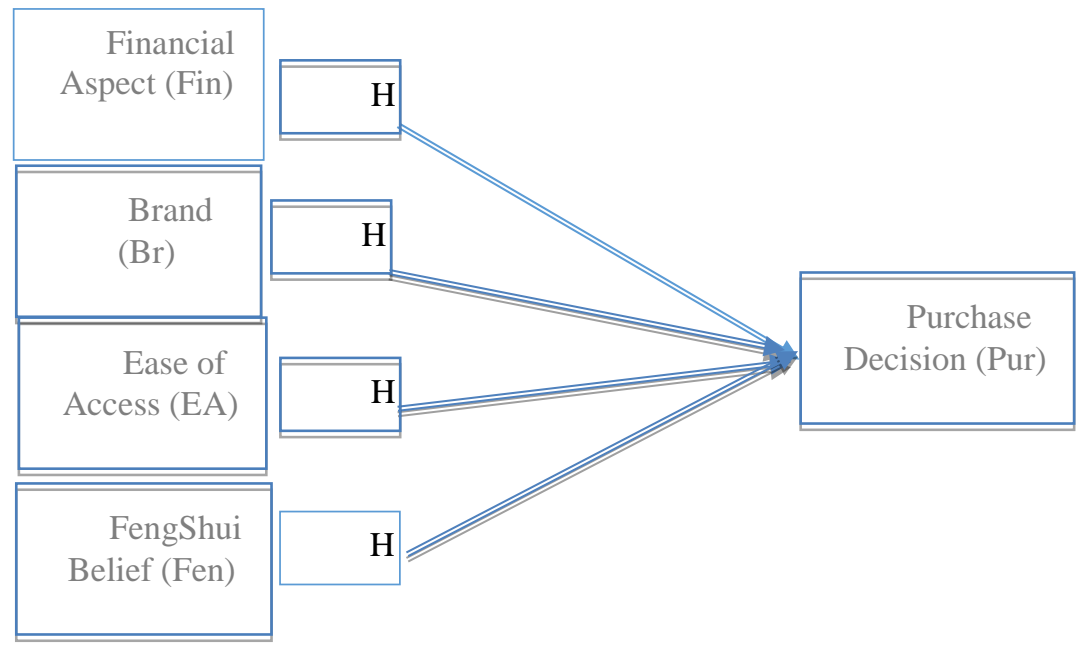

Figure 1. Research Model

The hypotheses developed are as follow:

H1: Financial aspect has significant effect on purchase decision

$\mathrm{H} 2$ : Brand Reputation has significant effect on purchase decision

H3: Ease of access has significant effect on purchase decision

H4: Feng shui confidence has significant effect on purchase decision

\section{Design and Method}

This research is a descriptive study with a quantitative approach. According to Sekaran and Bougie (2020) in descriptive research, connectivity between the independent variables and the dependent variable will be studied.This research was conducted to determine the influence of financial aspects, brand reputation, ease of access, and feng shui beliefs on the decision to buy house by millennials in the Greater Jakarta area during the current Covid-19 pandemic. 
The population in this study is the millennial generation in the greater Jakarta area area who have their owned income and familiar or aware of Feng Shui concept (Heriyati, Saiman, Kusumaningrum, Suria, 2020).

\subsection{Sample and Sampling Method}

Sample are taken from population, the millennial generation who live greater Jakarta area, have their income and have knowledge on feng shui belief. Sample are collected based on convenience sampling method. The determination of the number of samples in this study refers to the statement by Hair et al., 2011 that in determining the number of samples, it must be adjusted to the number of indicators used in the questions on the questionnaire. By using the formula $\mathrm{n} \times 5$ to $\mathrm{n} \times 10$ where $\mathrm{n}$ is the total indicator question on the questionnaire. This formula suggests that the minimum sample is $5-10$ observations for each indicator. In this study there are 19 indicators, therefore the total minimum sample size is 95 people as respondents. Data was collected by distributing offline andonline questionnaires to the respondents.

\subsection{Questionnaire Development}

In this study, the questionnaire was developed through the operationalization of four independent variables, namely Financial Aspect, Brand Reputation, Access, and Feng Shui belief which affect the dependent variable, namely Purchase Decision on housing or property.

Independent variables namely Financial aspect was measured by pricing, amount installment, rate of installment, bank financing easiness, and property cost maintenance (Eze \& Lim (2013); Agarwal et al., (2014); Kurniawan, et.al (2020)). Provider Brand was measured by dimensions namely brand reputation, brand awareness (Mulyano et al., (2020)). Access was measured by dimensions integration to transportation system, access to main road, access to public facilities, located in the city centre (Mulyano et al., (2020); (Jung et al., 2018). The Feng Shui Belief was measured by land position, room layout position, stairs position (Heriyati, Saiman, Kusumaningrum, Suria, 2020), and lastly, the dependent variable Purchase decision was measured by dimensions, preference property, liked the selected property, will buy the selected property (Stankevich, 2017).

\section{Data Analysis}

This study conducted data analysis of reliability and validity test and for hypotheses testing we will employ multiple regression analysis. We utilize SPSS Software and analysis tool to analyze the data.

\section{Result and Discussion}

This paper is intended to answer the research question of : 1) what is the factor of purchase decision of millennials in buying a house and 2) is the fengshui a significant factors instead of other factors. First, we will show the description result in Table 1, Table 2, Table 3, Table 4, and Table 5, Table 6, Table 7 and Table 8.

Table 1. Age Frequency

Age

\begin{tabular}{|c|l|l|l|l|l|}
\hline & Frequency & Percent & Valid Percent & $\begin{array}{c}\text { Cumulative } \\
\text { Percent }\end{array}$ \\
\hline 22 to 25 yo & 11 & 9,8 & 9,8 & 9,8 \\
26 to 30 yo & 38 & 33,9 & 33,9 & 43,8 \\
Valid & 31 to 35 yo & 45 & 40,2 & 40,2 & 83,9 \\
& 36 to 40 yo & 18 & 16,1 & 16,1 & 100,0 \\
Total & 112 & 100,0 & 100,0 & \\
\hline
\end{tabular}

Table 2. Marital Status Frequency

Marital_Status

\begin{tabular}{|l|l|l|l|l|}
\hline & Frequency & Percent & Valid Percent & $\begin{array}{c}\text { Cumulative } \\
\text { Percent }\end{array}$ \\
\hline Valid Yes & 74 & 66,1 & 66,1 & 66,1 \\
\hline
\end{tabular}




\begin{tabular}{|l|l|l|l|l|}
\hline No & 38 & 33,9 & 33,9 & 100,0 \\
Total & 112 & 100,0 & 100,0 & \\
\hline
\end{tabular}

Table 3. Domicile Frequency

Domicile

\begin{tabular}{|c|c|c|c|c|c|}
\hline & & Frequency & Percent & Valid Percent & $\begin{array}{l}\text { Cumulative } \\
\text { Percent }\end{array}$ \\
\hline \multirow{9}{*}{ Valid } & Centre Jkt & 6 & 5,4 & 5,4 & 5,4 \\
\hline & South Jkt & 11 & 9,8 & 9,8 & 15,2 \\
\hline & East Jkt & 5 & 4,5 & 4,5 & 19,6 \\
\hline & North Jkt & 10 & 8,9 & 8,9 & 28,6 \\
\hline & Bogor & 6 & 5,4 & 5,4 & 33,9 \\
\hline & Tangerang & 14 & 12,5 & 12,5 & 46,4 \\
\hline & Bekasi & 24 & 21,4 & 21,4 & 67,9 \\
\hline & Depok & 36 & 32,1 & 32,1 & 100,0 \\
\hline & Total & 112 & 100,0 & 100,0 & \\
\hline
\end{tabular}

Table 4. Education Frequency

Education

\begin{tabular}{|cc|c|c|c|c|}
\hline & Frequency & Percent & Valid Percent & $\begin{array}{c}\text { Cumulative } \\
\text { Percent }\end{array}$ \\
\hline \multirow{4}{*}{ Valid } & Diploma & 17 & 15,2 & 15,2 & 15,2 \\
& Bachelor & 73 & 65,2 & 65,2 & 80,4 \\
& Graduate & 22 & 19,6 & 19,6 & 100,0 \\
& Total & 112 & 100,0 & 100,0 & \\
\hline
\end{tabular}

Table 5. Occupation Frequency

Occupation

\begin{tabular}{|c|c|c|c|c|c|}
\hline & & Frequency & Percent & Valid Percent & $\begin{array}{l}\text { Cumulative } \\
\text { Percent }\end{array}$ \\
\hline \multirow{5}{*}{ Valid } & Government Employee & 17 & 15,2 & 15,2 & 15,2 \\
\hline & Private Employee & 33 & 29,5 & 29,5 & 44,6 \\
\hline & Entrepreneur & 39 & 34,8 & 34,8 & 79,5 \\
\hline & Professional & 23 & 20,5 & 20,5 & 100,0 \\
\hline & Total & 112 & 100,0 & 100,0 & \\
\hline
\end{tabular}

Table 6. Monthly Expenses Frequency 
Monthly_Expense

\begin{tabular}{|ll|l|l|l|l|}
\hline & Frequency & Percent & Valid Percent & $\begin{array}{c}\text { Cumulative } \\
\text { Percent }\end{array}$ \\
\hline \multirow{4}{*}{ Valid } & 1 to 7 mio & 16 & 14,3 & 14,3 & 14,3 \\
& 11 to 20 mio & 85 & 75,9 & 75,9 & 90,2 \\
& 21 to 30 mio & 11 & 9,8 & 9,8 & 100,0 \\
Total & 112 & 100,0 & 100,0 & \\
\hline
\end{tabular}

Table 7. Housing Type Frequency

Housing_Type

\begin{tabular}{|ll|l|l|l|l|}
\hline & Frequency & Percent & Valid Percent & $\begin{array}{c}\text { Cumulative } \\
\text { Percent }\end{array}$ \\
\hline \multirow{4}{*}{ Valid } & Residential & 55 & 49,1 & 49,1 & 49,1 \\
& Non Residential & 21 & 18,8 & 18,8 & 67,9 \\
& Apartement & 36 & 32,1 & 32,1 & 100,0 \\
& Total & 112 & 100,0 & 100,0 & \\
\hline
\end{tabular}

Table 8. Long of Stay Frequency

Long_of_Stay

\begin{tabular}{|c|c|c|c|c|c|}
\hline & & Frequency & Percent & Valid Percent & $\begin{array}{l}\text { Cumulative } \\
\text { Percent }\end{array}$ \\
\hline \multirow{3}{*}{ Valid } & 1 to 5 yrs & 69 & 61,6 & 61,6 & 61,6 \\
\hline & 6 to $10 \mathrm{yrs}$ & 43 & 38,4 & 38,4 & 100,0 \\
\hline & Total & 112 & 100,0 & 100,0 & \\
\hline
\end{tabular}

From Table 1 we have all millennials respondents (total of 112). Table 2 shows that $66 \%$ of them is married, and $33 \%$ not married. Table 3 shows that $32 \%$ respondents live in Depok, a city of $40 \mathrm{~km}$ to south from Jakarta, $21 \%$ lives in Bekasi, a city of $20 \mathrm{~km}$ north of Jakarta, $12 \%$ in Tangerang, $20 \mathrm{~km}$ to west from Jakarta, and about $32 \%$ live in Jakarta. Small percentage live in Bogor, $60 \mathrm{~km}$ in the south of Jakarta.

Table 4 shows $73 \%$ of respondents hold bachelor's degree, and $22 \%$ hold master's degree, and $17 \%$ hold diploma's degree. All of respondents is educated because they continue their study after high school. Table 5 shows that $44 \%$ are employees either in government or private sectors. We have $54 \%$ are entrepreneur and professional. All the respondents are job holders. The normal assumption is job holders want to seek their own house and consider buying a house for their family. Table 6 shows monthly expenses of $75 \%$ have 11 to 20 million rupiah per month, $9 \%$ has expenses between 21 to 30 million rupiah and $14 \%$ has monthly expenses of 1 to 7 million rupiah. Table 7 shows the need of housing type is $49 \%$ residential, $19 \%$ nonresidential, and $32 \%$ apartments. Table 8 shows the long of stay is $61 \%$ less than 5 years, and $38 \%$ is more than 5 years. With the installment of 5 to 7 million rupiah per month, our respondents are keen to buy their own house due to opening new area in the western Jakarta, with house price range between 200 million to 1 billion.

Table 9 shows the result of the buying decision with factors consist of financial aspect, company brand, location and feng shui belief. The fengshui belief is the only one that significant to buying decision. Other variables such as financial aspects, company brand and location show positive relation but insignificant to buying decision. 
Table 9. Regression Result of Buying Decision

Coefficients $^{\mathrm{a}}$

\begin{tabular}{|c|c|c|c|c|c|c|}
\hline \multirow{2}{*}{\multicolumn{2}{|c|}{ Model }} & \multicolumn{2}{|c|}{ Unstandardized Coefficients } & \multirow{2}{*}{\begin{tabular}{|c|}
$\begin{array}{c}\text { Standardized } \\
\text { Coefficients }\end{array}$ \\
Beta
\end{tabular}} & \multirow[t]{2}{*}{$\mathrm{t}$} & \multirow[t]{2}{*}{ Sig. } \\
\hline & & B & Std. Error & & & \\
\hline \multirow{5}{*}{1} & (Constant) & ,828 & ,905 & & ,915 & ,362 \\
\hline & Financial_Aspect & ,006 & ,099 & ,004 & ,059 & ,953 \\
\hline & Company_Brand & ,358 & 139 & ,211 & 2,577 & ,011 \\
\hline & Location & , 112 & , 166 & ,048 & ,674 & ,502 \\
\hline & FengShui_Belief & ,297 & ,031 & ,843 & 9,488 &, 000 \\
\hline
\end{tabular}

a. Dependent Variable: Buying_Decision

Table 10 shows that the R-square of buying decision model is $57,5 \%$. In other words, the factors in the model can explain $57,5 \%$ of buying decision, while $42,5 \%$ of the model is explained by other factors than financial aspect, company brand, location and fengshui belief.

Table 10. R-Square of Buying Decision Model

Model Summary ${ }^{\mathrm{b}}$

\begin{tabular}{|l|l|l|l|l|}
\hline Mode & $\mathrm{R}$ & $\mathrm{R}$ Square & $\begin{array}{c}\text { Adjusted } \\
\text { Square }\end{array}$ & Std. Error of the Estimate \\
\hline 1 &, $768^{\mathrm{a}}$ &, 590 &, 575 &, 18896 \\
\hline
\end{tabular}

a. Predictors: (Constant), FengShui_Belief, Location, Financial_Aspect, Company_Brand

b. Dependent Variable: Buying_Decision

\section{Conclusion}

This paper aims to examine the factors related to purchase decision in buying a house during the pandemic Covid-19 that now has been lasted for almost one year. The survey was taken during the pandemic and the respondents are informed that the answer in the survey is related to the pandemic time. From the result and discussion, we can conclude that the model of buying decision can be explained by the financial aspect, company brand, location and fengshui belief. The fengshui belief is the only variables that significantly affected the buying decision from millennials during the pandemic. The interesting phenomena is the millennials with all attributes of technology savvy, open, creative, informative, hence they still considered the traditional belief like fengshui to choose their home to live in. They still believe that good position of the house (and not the location) can affect their long-lasting stay and belief of welfare that will be given by the house. The basic needs of home sweet home.

We believe that this paper contributes to at least two things. First, the millennials in Indonesia especially, still hold on to traditional values to make the safety and the prosperity of their living. Second, the location of the house seemed irrelevant these days, due to easiness of transportation and the higher possibility of work from home policy, not only during the pandemic, but also for the future work policy. This study also gives insight that millennials prefer house and apartment to be their home.

We propose the further study in other belief from other culture to be one of the factors in buying a house, where this study can be done in country level. This opens a new opportunity to map how different beliefs can affect the buying decision. This will benefit the developer and business property owner in selling their property using the right marketing strategy with the local belief components.

\section{References}

Agarwal, S., Liu, C. H., Torous, W. N., \& Yao, V. W. (2014). Financial Decision Making When Buying and Owning a Home. SSRN Electronic Journal, 1-40. https://doi.org/10.2139/ssrn.2498111

Ali, H. \& Purwandi, L.(2017). Millenial Nusantara. Jakarta. PT Gramedia Pustaka Utama.

Anastasia, N. (2015). The Rational and Irrational Factors Underlying Property Buying Behavior. Journal of

Economics and Behavioral Studies, 7(2(J)), 183-191. https://doi.org/10.22610/jebs.v7i2(j).576 
Bisnis.Tempo.co.(2020). Pasar Properti Nasional Diprediksi Stabil di Kuartal Ketiga 2020. Retrieved from: https://bisnis.tempo.co/read/1351004/pasar-properti-nasional-diprediksi-stabil-di-kuartal-ketiga2020/full\&view=ok

Bougie, R. \& Sekaran, U.(2011). Research methods for business : A skill building approach (8th ed.).Danvers.John Wiley \& Sons,Inc.

Chang, C. P., \& Lin, C. M. (2015). The Influence of Wai Sha Feng Shui Factors on the Housing Price and House Buyers. Asian Journal of Humanities and Social Studies, 03(03), 2321-2799. www.ajouronline.com

Cheng, F., \& Cheok, J. (2008). Importance of branding for property developers in Malaysia. Sunway Academic Journal, 5, 65-81.

cnbcindonesia.com.(2020). 60\% industri lumpuh karena corona, bagaimana memulihkannya?. Retrieved from: https://www.cnbcindonesia.com/news/20200505162525-4-156501/60-industri-lumpuh-karena-coronabagaimana-memulihkannya

Covid19.go.id.(2020). Apa yang dimaksud dengan pandemi? .Retrieved from: https://covid19.go.id/tanyajawab?search=Apa\%20yang\%20dimaksud\%20dengan\%20pandemi?

Economy.okezone.com.(2019). Tips atur ruangan rumah menurut feng shui agar rejeki tak seret. .Retrieved from : https://economy.okezone.com/read/2019/02/06/470/2014268/tips-atur-ruangan-rumahmenurut-feng-shui-agar-rezeki-tak-seret

Ekonomi.bisnis.com.(2020). Ini Hal Yang Perlu Diantisipasi Pengembang Soal Gemuknya Pasar Milenial. Retrieved from : https://ekonomi.bisnis.com/read/20200212/47/1200668/ini-hal-yang-perlu-diantisipasipengembang-soal-gemuknya-pasar-milenial

Eze, U., \& Lim, Y. (2013). Indicators in the Purchase of Housing Properties. The Journal of Southeast Asian Research, 2013, 1-10. https://doi.org/10.5171/2013.432043

Fineberg, H. V. (2014). Pandemic Preparedness and Response - Lessons from the H1N1 Influenza of 2009. New England Journal of Medicine, 370(14), 1335-1342. https://doi.org/10.1056/nejmra1208802.

Hadiwardoyo, W. (2020). Kerugian Ekonomi Nasional Akibat Pandemi Covid-19. Baskara Journal of Business and Enterpreneurship, 2(2), 83-92. https://doi.org/10.24853/baskara.2.2.83-92

Hair, J. F., Ringle, C. M., \& Sarstedt, M. (2011). PLS-SEM: Indeed a silver bullet. Journal of Marketing Theory and Practice, 19(2), 139-152. https://doi.org/10.2753/MTP1069-6679190202

Hair, J. F., Sarstedt, M., Hopkins, L., \& Kuppelwieser, V. G. (2014). Partial least squares structural equation modeling (PLS-SEM): An emerging tool in business research. European Business Review, 26(2), $106-121$. https://doi.org/10.1108/EBR-10-2013-0128

Hair Jr., J. F., Matthews, L. M., Matthews, R. L., \& Sarstedt, M. (2017). PLS-SEM or CB-SEM: updated guidelines on which method to use. International Journal of Multivariate Data Analysis, 1(2), 107. https://doi.org/10.1504/ijmda.2017.10008574

Handayani, A.W. (2009). Pola atribut yang mempengaruhi preferensi konsumen dalam membeli rumah di Kecamatan depok, kabupaten sleman, provinsi daerah istimewa yogyakarta, tahun 2008. Journal Eknonomi dan Bisnis, 3(2), 91-105.

Harianhalmahera.com. (2020). WHO :Waspada ada pandemi lain usai corona. Retrieved from :https://harianhalmahera.com/mancanegara/who-waspada-ada-pandemi-lain-usai-corona/

Hei, C. P., \& Dastane, O. (2017). Buying a Dream Home - Considerations of Residential Property Consumers in Malaysia. Singaporean Journal of Business Economics and Management Studies, 5(9), 19-35. https://doi.org/10.12816/0037222

Heriyati, P., Saiman, N.I.D., Kusumaningrum, R., \& Suria, R.S., (2020) The Influence of fengshui belief, superstition belief, and relatives reference belief on house buying decision in jakarta greater area. Journal of Solid State Technology, 63(4), 2020.

Iacobucci, D. (2018). Order directly from Amazon : Iacobucci \& Churchill, Marketing Research : September.

IDN Research Institute.(2019). Indonesia Millenial Report 2019. Retrieved from https://cdn.idntimes.com/content-documents/indonesia-millennial-report-2019-by-idn-times.pdf

Badan Pusat Statistik (2018). Statistik gender tematik: profil generasi milenial indonesia. Jakarta, Indonesia :Kerjasama Kementerian Pemberdayaan Perempuan dan Perlindungan Anak dengan Badan Pusat Statistik . Retrieved from : https://www.kemenpppa.go.id/lib/uploads/list/9acde-buku-profil-generasi-milenia.pdf

Jamil, F. (2015). The Role of Installment Buying Plans in Increasing the Impulse Buying Behavior among Jordanian House Holds. Journal of Management Research, 8(1), 110. https://doi.org/10.5296/jmr.v8i1.8625

Jung, C., Zhu, J., Goodman, L., Ganesh, B., \& Strochak, S. (2018). Millennial Homeownership Why Is It So Low, and How Can We Increase It? July, https://www.urban.org/sites/default/files/publication/98729/millennial_homeownership.pdf

Kauko, T. (2006). What makes a location attractive for the housing consumer? Preliminary findings from metropolitan Helsinki and Randstad Holland using the analytical hierarchy process. In Journal of Housing and the Built Environment (Vol. 21, Issue 2, pp. 159-176). https://doi.org/10.1007/s10901-006-9040-y

Kbbi.kemdikbud.go.id.(2020). Milenial .Retrieved from: https://kbbi.kemdikbud.go.id/entri/milenial 
Kemenpppa.go.id.(2018). Profil generasi milenial indonesia. Retrieved from : https://www.kemenpppa.go.id/lib/uploads/list/9acde-buku-profil-generasi-milenia.pdf

Kinnear, T.C., \& Taylor, J,R., Lamarto, Y. (Penerjemah). (1992). Riset pemasaran : pendekatan terpadu (3rd edition). Erlangga.

Kurniawan, C., Dewi, L. C., Maulatsih, W., \& Gunadi, W. (2020). Factors influencing housing purchase decisions of millennial generation in Indonesia. International Journal of Management, 11(4), 350-365. https://doi.org/10.34218/IJM.11.4.2020.035

Kottler,A. \& Keller, K.L.(2016). Marketing management : creating value (15th ed). Essex, England :Pearson Education Limited.

Kwong, K. \& Wong, K., (2013). Partial Least Squares Structural Equation Modeling (PLS-SEM) Techniques Using SmartPLS. Marketing Bulletin, 24, 1-32.

Liu, W., Yue, X. G., \& Tchounwou, P. B. (2020). Response to the covid-19 epidemic: The chinese experience and implications for other countries. International Journal of Environmental Research and Public Health, 17(7), 1-6. https://doi.org/10.3390/IJERPH17072304.

Maoludyo, F. T., \& Aprianingsih, A. (2015). Factors Influencing Consumer Buying Intention for Housing Unit in Depok. Journal of Business and Management, 4(4), 484-493.

Mariadas, P. A., Abdullah, H., \& Abdullah, N. (2019). Factors Affecting Purchasing Decision of Houses in the Urban Residential Property Market in Klang Valley, Malaysia. E-Bangi, 16(4), 1-9.

Moreno, F. M., Lafuente, J. G., Carreón, F. Á., \& Moreno, S. M. (2017). The Characterization of the Millennials and Their Buying Behavior. International Journal of Marketing Studies, 9(5), 135. https://doi.org/10.5539/ijms.v9n5p135

Mulyano, Y., Rahadi, R. A., \& Amaliah, U. (2020). Millennials Housing Preferences Model in Jakarta. European Journal of Business and Management Research, 5(1), 1-9. https://doi.org/10.24018/ejbmr.2020.5.1.240

Pathirathna, R., Adikari, P., Dias, D., \& Gunathilake, U. (2020). Critical Preparedness, Readiness and Response To Covid-19 Pandemic: a Narrative Review. Jurnal Administrasi Kesehatan Indonesia, 8(2), 21. https://doi.org/10.20473/jaki.v8i2.2020.21-34

Propertyindonesia.co.id.(2020). Properti adalah pengertian definisi property. Retrieved from : https://www.propertyindonesia.co.id/properti-adalah-pengertian-definisi-property/

Properti.kompas.com.(2020). Masa pandemi virus, momentum emas bagi milenial untuk beli properti. Retrieved from : https://properti.kompas.com/read/2020/05/20/184700721/masa-pandemi-virus-momentum-emas-bagimillennial-untuk-beli-properti

Rahadi, R. A., Wiryono, S. K., Koesrindartoto, D. P., \& Syamwil, I. B. (2013). Attributes Influencing Housing Product Value and Price in Jakarta Metropolitan Region. Procedia - Social and Behavioral Sciences, 101, 368-378. https://doi.org/10.1016/j.sbspro.2013.07.211

Rahadi, R. A., Wiryono, S. K., Koesrindartoto, D. P., \& Syamwil, I. B. (2015). Factors influencing the price of housing in Indonesia. International Journal of Housing Markets and Analysis, 8(2), 169-188

Ramya, N. \& Mohamed, A. (2016). Factors affecting consumer buying behaviour. International Journal of Applied Research 2(10) : 76-80.

RealEstate.Id. (2020). Pasar perumahan jabodetabek - banten : penjualan melonjak, pasar bergeser. Retrieved from : https://realestat.id/berita-properti/pasar-perumahan-jabodebek-banten-penjualan-melonjak-segmenpasar-bergeser/

Redjo, R.E.S.M., Wijayaningtyas, M., \& Iskandar, T. (2019). Keputusan pembelian rumah generasi milenial kota malang. Jurnal Teknik Sipil Info Manpro, 4(2), 1-9.

Rumah.com.(2020). Bagaimana dampak covid - 19 terhadap harga properti dan dimana peluangnya?. Retrieved from: https://www.propertyindonesia.co.id/properti-adalah-pengertian-definisi-property/

Sean, S. L., \& Hong, T. T. (2014). Factors Affecting the Purchase Decision of Investors in the Residential Property Market in Malaysia. Journal of Surveying, Construction \& Property, 5(2), 1-13. https://doi.org/10.22452/jscp.vol5no2.4

Sia, M. K., \& Lu, L. C. (2006). Feng shui and buying house. Jurutera, December, 20-27.

Stankevich, A. (2017). Explaining the Consumer Decision-Making Process: Critical Literature Review. Journal of International Business Research and Marketing, 2(6), 7-14. https://doi.org/10.18775/jibrm.18498558.2015.26.3001

Student-activity.binus.ac.id. (2017). Probability sampling vs non - probability sampling. Retrieved from : https://student-activity.binus.ac.id/himsisfo/2017/03/probability-sampling-vs-non-probability-sampling/

Sugiyono, Prof. Dr. (2015). Metode Penelitian Kuantitatif Kualitatif dan R\&D

Sulistyawati, D., \& Santosa, I. (2019). Pengaruh Perilaku Budaya Generasi Milenial Menghadapi Revolusi Industri terhadap Ruang Hunian Pribadi dengan Studi Kasus “One Room Living” Mahasiswa. The Indonesian Design Journal, 1(1), 24-30.

Ticoalu, J.M., Jaya, N.A.A.T., (2019). Faktor yang mempengaruhi customer continuance intention dalam penggunaan e-money (studi kasus pada pengguna ovo di jakarta).Thesis Binus Business School. 
Who.int. (2020). Pertanyaan dan jawaban terkait coronavirus. Retrieved from : https://www.who.int/indonesia/news/novel-coronavirus/qa-for-public

Wulandari, A.E., Oktafiana, B., Faqih, M., Hayati. A., (2016). Upper-Middle Society Preference in Indonesia in Selecting a Dwelling. International Journal of Engineering Research and Technology (IJERT), 5(1), 90-95. www.ijert.org 